\title{
DE MAXIMIS NON CURAT PRAETOR OR JUDICIAL RE- VIEW: THE HAGUE COURT IN A TIME OF TRANSITION*
}

\author{
Fredrik Danelius $^{* *}$
}

\section{INTRODUCTION}

More than thirty years have passed since the death of one of the greatest international lawyers of this century, Sir HERSCH LAUTERPACHT (1897-1960). In 1933 he published what may be his finest academic achievement, The Function of Law in the International Community, a piece of work which still today exercises its influence upon the international legal debate. The book deals with a number of essential problems of international law - and, indeed, in many instances, law generally - concerning the role of law and courts in the international society.

LAUTERPACHT devotes two chapters to a critical examination of a view "the doctrine De maximis non curat praetor" - which in his opinion has exercised an unfortunate influence upon the organization and administration of international justice. ${ }^{1}$ According to the criticized doctrine, there is a certain kind of disputes which do not belong in courts of law, namely disputes in which the vital interests of states are at stake. This doctrine is unsound, LAUTERPACHT argued:

“. . . in so far as the vital interests of States require protection, they are better protected by the recognition of the reign of law administered through international tribunals than by formally safeguarding, through the usual reservations, the ultimate right to have recourse to force."2

\footnotetext{
* A shorter Swedish language version of this article has been published in 78 Svensk Juristtidning [The Swedish Law Journal] (1993) 854-862. It was awarded the Journal's annual prize in 1993 as best article of a young professional lawyer.

** Researcher in International Law, University of Lund, Sweden.

${ }^{1}$ H. LAUTERPACHT, The Function of Law in the International Community (1933) 166-201. The Latin phrase may be translated "The judge does not deal with big issues". The phrase is a travesty of the Roman law maxim de minimis non curat praetor (The judge does not deal with small issues).

${ }^{2}$ Ibid., p. 177.
}

Asian Yearbook of International Law, Volume 5 (Ko Swan Sik et al., eds.; 90-411-0375-9

(c) 1997 Kluwer Law International; printed in the Netherlands), pp. 3-13 
LAUTERPACHT's view, which in 1933 may have appeared to many observers as a quite unrealistic expression of 'judicial idealism', gradually gained acceptance during the first decades of the Post-World War II-era. ${ }^{3}$ After the adoption of the UN Charter (of which the new Statute of the Hague Court forms an integral part) in 1945 many disputes which had previously been considered exclusively political were now to be regarded (also) as legal ones and therefore as capable of being subjected to judicial settlement.

The recent practice of the Hague Court has re-opened the debate on the role of the Court in 'political' disputes. The picture which emerges from the decisions of the Court, from the pleadings of the state parties and from the academic debate in recent years is not, however, an absolutely clear one. On the one hand, a tendency towards a revival of the doctrine de maximis . . . may be noted. On the other hand, moves towards an enhancement of the role of the Hague Court in world politics are also part of the picture.

Here I intend to discuss the appropriateness and the possible effects of a revival of the doctrine de maximis . . . as a guiding maxim for the work of the Hague Court. First I intend to examine the place of this doctrine in the written rules concerning the Court's jurisdiction and the admissibility criteria applicable to cases before the Court (section 2). Thereafter I will discuss the possible impact of the doctrine on the exercise of the judicial function, first from a theoretical perspective (section 3), then from the perspective of the practice of the Court (section 4). By way of conclusion I intend to propose a particular judicial approach to the doctrine de maximis non curat praetor (section 5).

\section{THE PLACE OF THE DOCTRINE VIS-A-VIS THE JURISDICTION OF THE HAGUE COURT AND THE ADMISSIBILITY OF THE CLAIM}

The doctrine de maximis non curat praetor has had a particular impact on the treaties on international arbitration and adjudication which were concluded in the late 19th century and the early 20th century. Quite early in the history of modern international adjudication a distinction was made between legal and political disputes, of which only the former were considered suitable for submission to international tribunals. ${ }^{4}$ Maintaining freedom of action in

\footnotetext{
${ }^{3}$ I. BROWNLIE, 'The justiciability of disputes and issues in international relations', 42 BYIL (1967), at p. 124, has commented upon LAUTERPACHT's view on these and some closely related matters: "To some extent these propositions may now seem obvious but until LAUTERPACHT's book appeared they were probably not generally accepted."

${ }^{4}$ LAUTERPACHT, op. cit. n. 1 at pp. 6-9, traces the distinction to E. DE VATTEL's influential treatise Le Droit des Gens, ou Principes de la Loi Naturelle, appliqués à la Conduite et aux Affaires des Nations et des Souverains (1758).
} 
political disputes was however, according to the long-prevailing view, necessary in order not to undermine state sovereignty. As a consequence of this predominant view, a practice emerged in the late 19th century of including into arbitration treaties a clause which excluded from arbitration disputes affecting "the vital interests, the independence or the honour of the two contracting States".$^{5}$ Normally, each state party to such a treaty reserved the right for itself to determine when its vital interests or the like were at stake. By safeguarding their positions as authoritative interpreters of these treaties, states did not only protect their sovereignty. They also reduced the practical value of the numerous attempts which were made to elaborate criteria or 'tests' for distinguishing between legal and political disputes. ${ }^{6}$

In the words of the Statute of the Hague Court, the Court's 'compulsory' jurisdiction is still today limited to 'legal disputes', namely:

"all legal disputes concerning

a. the interpretation of a treaty;

b. any question of international law;

c. the existence of any fact which would constitute a breach of an international obligation;

d. the nature or extent of the reparation to be made for the breach of an international obligation."

Nevertheless, for two reasons it is clear that a state which has made an unconditional declaration under 'the optional clause' (thus accepting the jurisdiction of the Court in its future legal disputes) must be considered to have renounced a significant part of its freedom to interpret the scope of 'legal disputes'. Firstly, the Hague Court has been granted compétence de la compétence, i.e. the power to decide its own jurisdiction. ${ }^{8}$ Secondly, the restriction of the Court's jurisdiction to 'legal disputes' has hardly the same significance today as it had at the turn of the century. Many areas which used

\footnotetext{
${ }^{5}$ The example is from the Franco-British Arbitration Treaty of 14 October 1903, Art. 1, and quoted after LAUTERPACHT (op. cit. n. 1, at p. 30, n. 3). According to LAUTERPACHT the same formula appeared in 15 other arbitration treaties concluded by Great Britain in these years.

${ }^{6}$ On this issue, see, e.g., T. GIHL, " "The Subjective Test" as a means of distinguishing between legal and political disputes', 8 Acta scandinavica juris gentium (1937) 67-107.

${ }^{7}$ Article 36 para. 2 of the ICJ Statute. For the Court's own understanding of the phrase "legal dispute" in this Article, see Border and Transborder Armed Actions (Nicaragua v. Honduras), ICJ Rep. 1988, p. 91, where the Court defines a legal dispute as "a dispute capable of being settled by the application of principles and rules of international law".

${ }^{8}$ Article 36 para. 6 of the ICJ Statute. For the Court's own conception of its compétence de la compétence, see Nottebohm (Liechtenstein v. Guatemala), ICJ Rep. 1953, pp. 119-120, and Arbitral Award of 31 July 1989 (Guinea-Bissau v. Senegal), ICJ Rep. 1991, at p. 68.
} 
to be considered exclusively political or 'matters of domestic jurisdiction' have since been subjected to international regulation and have in this way been internationally 'legalized'. Even matters relating to the threat or use of force between nations, which once were considered political to a particularly high degree, are today legal in the sense that they are subjected to the law of the United Nations Charter (and also, at least in the view of the Hague Court in the Nicaragua case $^{9}$, to customary international law). HERMANN MOSLER, a former judge of the Hague Court, has described the present scope of the Court's jurisdiction under the optional clause in these plain terms:

"It is a truism to remember that any legal dispute has political implications. [. . . T There is no doubt that an unconditional declaration under the Optional Clause accepting the Court's jurisdiction includes legal disputes involving political elements of every gradation." 10

The conclusion has to be that the confinement of the Court's compulsory jurisdiction to legal disputes is not, as international law stands today, to be understood as an expression of the doctrine de maximis non curat praetor.

It may also be asked whether the doctrine de maximis . . . could be significant as an element in a rule of litispendence between the Court and the political organs of the United Nations. ${ }^{11}$ The Hague Court took a clear stand on this matter in the Hostages case. ${ }^{12}$ Here, the Court faced the problem whether it should consider on its merits a case involving a dispute which was on the agenda of the UN Security Council. The Court clearly rejected the proposition that the fact that the Council deals or has dealt with a certain dispute prevents the Court from considering a case involving the same dispute upon its merits. ${ }^{13}$

\footnotetext{
${ }^{9}$ Military and Paramilitary Activities in and against Nicaragua (Nicaragua $v$. United States of America), ICJ Rep. 1986 p. 88 et seq.

${ }^{10} \mathrm{H}$. MOSLER, 'Political and justiciable legal disputes: revival of an old controversy?', in: B. CHENG \& E.D. BROWN (eds.), Contemporary Problems of International Law: Essays in Honour of Georg Schwarzenberger on His Eightieth Birthday (1988) p. 221-222.

${ }^{11}$ See, e.g., D. Ciobanu, 'Litispendence between the International Court of Justice and the political organs of the United Nations', in: L. Gross (ed.), The Future of the International Court of Justice, Vol. 1 (1976) pp. 209-275; and T.J.H. ELSEN, Litispendence between the International Court of Justice and the Security Council (1986).

${ }^{12}$ United States Diplomatic and Consular Staff in Teheran (United States of America $v$. Iran), ICJ Rep. 1979, 1980 and 1981.

${ }^{13}$ See, in particular, ICJ Rep. 1980 pp. 21-22 and ICJ Pleadings, United States Diplomatic and Consular Staff in Teheran, at p. 29.
} 


\section{THE IMPACT OF THE DOCTRINE FROM A THEORETICAL PERSPECTIVE}

In a contentious case a court has to satisfy itself that the dispute falls within its jurisdiction and that the claim is admissible before it proceeds to consider the case upon its merits. Jurisdiction and admissibility may in other words be described as necessary conditions for a judgment on the merits. But are they also sufficient conditions? Does the fact that a court has jurisdiction and that a claim is admissible imply a duty for the court to consider the case upon its merits? In many legal systems these questions are answered in the affirmative. Closely connected with the very ideas of the rule of law and der Rechtsstaat is the idea of the completeness of the law and its corollary, the prohibition of non liquet. A Court is not allowed to refrain from deciding a case on its merits with a reference to the lack of applicable law or to the lack of clarity of the existing law. What may appear to be a lacuna in the law is only a lacuna prima facie; the law has always an answer, and it is the professional duty of the judge to find it. The judge who pronounces a non liquet may even be held personally responsible for denial of justice.

Does the prohibition of non liquet also apply to the Hague Court? Or may the Court decide not to examine a contentious case on its merits even when the formal requirements for doing so are fulfilled? ${ }^{14}$ If the latter question were to be answered in the affirmative this would break ground for a revival of the doctrine de maximis . . . in international adjudication, with the difference that this time the doctrine would not appear as a formal jurisdictional rule but as an element of judicial policy. Among academic writers the prohibition of non liquet has since some time been a matter of controversy. On the one hand,

\footnotetext{
${ }^{14}$ When asked for an advisory opinion the Court has, under its Statute, no strict duty to give an opinion. Article 65 para. 1 of the Statute only says that "[t]he Court may give an advisory opinion on any legal question" (emphasis added) to any body which has the power to make such a request. In its practice the Court has, however, repeatedly stated that, in principle, the request for an advisory opinion should not be refused. See e.g. Interpretation of Peace Treaties (Advisory Opinion), ICJ Rep. 1950 pp. 71-72, or, even stronger, Judgments of the Administrative Tribunal of the ILO (Advisory Opinion), ICJ Rep. 1956 p. 86. In fact, the Hague Court has so far only once declined to give an opinion, namely in the case Status of Eastern Carelia, PCIJ, Ser. B, No. 5 (1923). It is interesting to note that one of the States whose interests were at stake in the old Eastern Carelia case, namely Finland (which did not challenge the propriety of the Court giving an opinion in this case; Russia did!), has recently argued that the Court should decline to give an opinion in Legality of the Use by a State of Nuclear Weapons in Armed Conflict (Request for Advisory Opinion by the WHO) and Legality of the Threat or Use of Nuclear Weapons (Request for Advisory Opinion by the General Assembly of the UN). For a summary of the Finnish argument in these cases, see P. KAUKORANTA, 'Finland', in: Elements of the International Legal Practice of the Nordic States in 1995, 65 Nordic Journal of International Law no. 2 (1996) (forthcoming).
} 
'judicial idealists' like HERSCH LAUTERPACHT have argued that the prohibition is part of positive international law, and for good reasons. ${ }^{15}$ On the other hand, 'judicial realists' like JULIUS STONE and, lately, HJALTE RASMUSSEN have suggested that the Hague Court has an option - perhaps even a duty to pronounce a non liquet (be it explicit or 'cryptic) in cases where a judgment on the merits would be counter-productive in the efforts to obtain a just and peaceful settlement of the dispute. ${ }^{16}$

The idea of an option of non liquet has a clear link to a particular version of the distinction between justiciable and non-justiciable disputes. This distinction may be, and has indeed often been, perceived as identical with the distinction between legal and political disputes. Some observers, however, have understood the distinction in a slightly different sense. As already mentioned, the concept of legal dispute has gradually become a rather widely interpreted notion of, inter alia, Article 36 paragraph 2 of the Statute of the Hague Court. As distinct therefrom, a justiciable dispute could simply be understood as a dispute which is fit for judicial settlement. ${ }^{17}$ According to what has been called 'the doctrine of justiciability' it would be good judicial policy if decisions on the merits were to be taken by the Court only in regard to such disputes as are justiciable. ${ }^{18}$

\footnotetext{
${ }^{15}$ In the view of H. LAUTERPACHT (in: The Development of International Law by the International Court (1958) 165-167), Article 38 para. 3 of the Statute of the Court referring to "general principles of law as recognised by civilised States" serves as "an ultimate safeguard against the possibility of a non liquet" (p. 166). Recently, M. KosKENNIEMI (in: From Apology to Utopia (1989) 35-40) has pointed out the parallels between LAUTERPACHT's "constructivism" and some influential streams in modern legal theory (RONALD DWORKIN and others), stressing the role of principles in ensuring the completeness and coherence of law as applied by Courts. ${ }^{16}$ See, in particular, the so-called Lauterpacht-Stone controversy: H. LAUTERPACHT, 'Some Observations on the Prohibition of "Non Liquet" and the Completeness of the Law', originally published in 1958 and reprinted in: E. LAUTERPACHT (ed.), International Law, being the Collected Papers of Hersch Lauterpacht, Vol. 2 (1975) 213-237; and J. STONE, 'Non liquet and the function of law in the international community', 35 BYIL (1959) 124-161. For a revised and extended version of STONE's contribution, see J. STONE, Of Law and Nations (1974) 71-118. See, also, H. RASMUSSEN, 'Le juge international, en évitant de statuer obéit-il à un devoir judiciaire fondamental?', 29 GYIL (1986) 252-276.

${ }^{17}$ Cf. C. DE VISSCHER, Theory and Reality in Public International Law (P.E. CoRBETT transl.), rev. ed. (1968) 370-376; and P. CHAPAL, L'arbitrabilité des différends internationaux (1967) 4345.

${ }^{18}$ See P.M. NoRTon, 'The Nicaragua Case: Political Questions before the International Court of Justice', 27 Virginia Journal of International Law (1987) 492-524.
} 


\section{THE IMPACT OF THE DOCTRINE FROM A PRACTICAL PERSPECTIVE}

It has happened more than once that a defendant state before the Hague Court took the position that the dispute under consideration was nonjusticiable. ${ }^{19}$ The argument has not found favour with the Court except, perhaps, in a rather special judgment which was given in the Northern Cameroons case. ${ }^{20}$ In this case Cameroon requested the Court to declare that the United Kingdom had not acted in accordance with certain duties embodied in a trusteeship agreement. Without finding it necessary to examine several British objections to the jurisdiction of the Court and the admissibility of the claim, the Court declared that the case would not be tried on its merits. In explaining this position, which in the eyes of many observers appeared quite peculiar, the Court declared, inter alia:

“. . . even if the Court, when seised, finds that it has jurisdiction, the Court is not compelled in every case to exercise that jurisdiction. There are inherent limitations on the exercise of the judicial function which the Court, as a court of justice, can never ignore."21

It may seem as if the Court, in and through its judgment in the Northern Cameroons case, accepted the doctrine of justiciability. Considering the exceptional character of the claim (a demand for a declaratory judgment, as understood by the Court ${ }^{22}$ ) and the fact that the judgment still appears to be unique in the practice of the Court, one must be careful not to draw too farreaching conclusions from the statement quoted above. ${ }^{23}$

The questions surrounding the doctrine de maximis . . . and the doctrine of justiciability became the focus of attention once more when, on 9 April 1984, Nicaragua filed an application to the Hague Court against the United States of America. ${ }^{24}$ Herein, the United States was accused of violating international law by conducting and supporting military and paramilitary

\footnotetext{
${ }^{19}$ In some instances (see further infra) this argument has been made openly before the Court. In other instances the defendant state has expressed its disapproval of the proceedings by failing to appear before the Court. For an inquiry into the links between non-appearance and (alleged) nonjusticiability, see J.B. ELKIND, Non-Appearance before the International Court of Justice: Functional and Comparative Analysis (1984) 171-206.

${ }^{20}$ Northern Cameroons (Cameroon v. United Kingdom), ICJ Rep. 1963.

${ }^{21}$ Ibid., at p. 29.

22 Ibid., at p. 36.

${ }^{23}$ For a critical assessment of the Northern Cameroons judgment, see, e.g., L. GRoss, 'Limitations upon the Judicial Function', 58 AJIL (1964) 415-431.

${ }^{24}$ Military and Paramilitary Activities in and against Nicaragua (Nicaragua $v$. United States of America), ICJ Rep. 1984 (jurisdiction) and 1986 (merits).
} 
activities in and against Nicaragua. The United States made several objections against the jurisdiction of the Court and the admissibility of the claim. The United States further demanded that the Court, in case it would find itself competent to entertain the case on its merits, still should refrain from doing so since the dispute was not fit for judicial settlement:

“. . . an 'ongoing armed conflict' involving the use of armed force contrary to the Charter is one with which a court cannot deal effectively without overstepping proper judicial bonds". ${ }^{25}$

In both phases of the case the Court rejected this argument in rather brief words. ${ }^{26}$

The American argumentation in the Nicaragua case was clearly influenced by US constitutional theory and its particular version of the doctrine de maximis . . ., namely the 'political question doctrine'. The latter doctrine, which goes back to the early 19th century, implies in brief that courts shall show self-restraint in the exercise of their judicial powers in politically sensitive cases. ${ }^{27}$ In the practice of the United States Supreme Court the doctrine has been applied, inter alia, when issues relating to foreign affairs have appeared on the agenda of the Court. In a recent critical examination THOMAS FRANCK has described the doctrine as a 'Faustian Pact' concluded between the courts and the political organs of the land. ${ }^{28}$ According to FRANCK the doctrine was the price that the legendary Chief Justice JAMES MARSHALL had to pay in order to gain acceptance for his bold initiative to introduce judicial review as an American constitutional practice in the famous case Marbury v. Madison in $1803 .^{29}$

Should the Hague Court's apparent reluctance to accept the American attempt to 'export' the political question doctrine in the Nicaragua case be understood as once and for all dispatching the doctrine de maximis non curat praetor to the history of international adjudication? Perhaps this would be a too far-reaching conclusion. In connection with a couple of recent cases in the

\footnotetext{
${ }^{25}$ ICJ Rep. 1986, at p. 26. For an extended version of this argument, see P.M. NORTON, loc. cit. n. 18, pp. 459-526. This article is of particular interest for the understanding of the American arguments, since Norton was the deputy agent of the United States in this case.

${ }^{26}$ ICJ Rep. 1984, pp. 436-438 and ICJ Rep. 1986, pp. 26-28.

${ }^{27}$ The political question doctrine is a matter of constant controversy. See, e.g., L. HENKIN, 'Is there a "Political Question" Doctrine?', 85 Yale Law Journal (1976) 597-625.

${ }^{28}$ T.M. FRANCK, Political Questions - Judicial Answers: Does the Rule of Law Apply to Foreign Affairs? (1992) 10-20.
}

${ }^{29} 5$ U.S. 137 (1803). 
Hague Court, which are still in their initial stages - the Lockerbie cases ${ }^{30}$ and the Bosnian case ${ }^{31}$ - it has once again been questioned whether 'political' disputes of this kind are really suitable for judicial settlement. Such disputes should instead, so it has been argued, be settled by diplomatic, political or even military means.

\section{A JUDICIAL APPROACH TO THE DOCTRINE}

For many reasons lawyers may feel inclined to favour the widest possible space for courts, both at the national and the international level. Indeed, nothing would be simpler than recommending the Hague Court - on the basis of considerations relating to the pre-eminence of the law - to continue suppressing the doctrine de maximis . . ., to uphold the prohibition of non liquet and - with the judicial strategy of Chief Justice MARSHALL in Marbury v. Madison as a model - to start exercising judicial review of the resolutions of the Security Council. ${ }^{32}$ Good reasons for the international society to organize itself along these lines are to be found in the writings of e.g. HERSCH LAUTERPACHT and THOMAS FRANCK. For many others, however, a world order modelled in such a way may either be an idle wish or a faraway goal.

This being said, it is still necessary to consider certain historical experiences, which are here summarized in HERMANN MOSLER's words:

"Speaking in terms of historical experience and the development of modern States in the last few centuries the importance and the effectiveness of the judiciary have always been an indicator of the degree of integration reached by a social community." 33

The international society has hardly reached such a degree of integration that the Hague Court could reasonably function as a court for the United Nations and the community of states in a manner similar to that of the highest courts

\footnotetext{
${ }^{30}$ Questions of Interpretation and Application of the 1971 Montreal Convention arising from the Aerial Incident at Lockerbie (Libyan Arab Jamahiriya v. United Kingdom and Libyan Arab Jamahiriya $v$. United States of America), ICJ Rep. 1992.

${ }^{31}$ Application of the Convention on the Prevention and Punishment of the Crime of Genocide (Bosnia and Herzegovina $v$. Yugoslavia (Serbia and Montenegro)), ICJ Rep. 1993.

${ }^{32}$ THOMAS FRANCK has detected judicial moves in this direction in the Court's orders of 14 April 1992 in the Lockerbie cases (supra note 30). See T.M. FRANCK, 'The 'Powers of Appreciation': Who is the ultimate guardian of UN legality?', 86 AJIL (1992) 519-523. For the assertion that the Court "has in fact repeatedly exercised a power of judicial review, albeit deferentially, over acts by the Security Council and the General Assembly", see G.R. WATSON, 'Constitutionalism, Judicial Review and the World Court', 34 Harvard International Law Journal (1993) 1-45.

${ }^{33}$ H. MOSLER, loc. cit. supra n. 10 at p. 220.
} 
in the most integrated (federal) legal systems. Those who would like to see an enhanced role of international law and the Hague Court in the international community should, therefore, not confine themselves to exercising the noble art of wishful thinking, but also ask themselves in what ways the position of the Court at present could realistically be enhanced.

It has been noted that the unprecedented length of MANFRED LACHS'S term of service as a judge (1967-1993) was in many respects a time of renewal for the Court. ${ }^{34}$ The bloodless legalism which had left its mark on the inter-war Court and the first decades of the post-war Court was challenged by new perspectives. In addition to its function as a law-applying agency, the functions of the Court as a part of the United Nations system and as an agency for dispute-resolution were increasingly emphasized, the latter tendency being an element in what GEORGES ABI-SAAB has called "cette tendance vers l'arbitralisation de la Cour". ${ }^{35}$ In this perspective the Court's failure even to discuss the possibilities of making a distinction between justiciable and non-justiciable disputes in the Nicaragua judgment is somewhat surprising. More elucidating in this respect is actually the separate opinion of MANFRED LACHS. In his opinion LACHS kept a door open for the doctrine of justiciability, even though he considered the Nicaragua dispute justiciable:

"Thus it becomes clear that the dividing line between justiciable and nonjusticiable disputes is one that can be drawn only with great difficulty. It is not the purely formal aspects that should in my view be decisive, but the legal framework, the efficacy of the solution that can be offered, the contribution the judgment may make to removing one more dispute from the overloaded agenda of contention the world has to deal with today." ${ }^{\text {36 }}$

The position taken by LACHS clearly appears more flexible and realistic than the relapse into escapistic legalism which characterized this part of the Court's Judgment.

The Hague Court arrived at a crossroads when dealing with the Lockerbie cases and the Bosnian case in their initial stages. In these cases the applicants tried, inter alia, to induce the Court to express an opinion on the conformity with the UN Charter of certain resolutions adopted by the UN Security Council. Considering the far-reaching and inconclusively delimited powers of

\footnotetext{
${ }^{34}$ L.V. ProtT, 'The Judicial Philosophy of Manfred Lachs', in: Essays in International Law in Honour of Judge Manfred Lachs, (J. MAKARCZYK ed., 1984) at 423-447.

35 G. ABI-SAAB, 'De l'évolution de la Cour Internationale: Réflexions sur quelques tendances récentes', 96 Revue Génerale de Droit International Public (1992) 284-293.

36 ICJ Rep. 1986 at p. 168.
} 
the Council, it ought to be welcomed if the Court would reserve for itself such a function. At the same time it must be acknowledged that even a weak version of judicial review would seem provocative in the eyes of many states, including a majority of those occupying a permanent seat in the Security Council. If the Hague Court is to strengthen its position, this would demand a skilful manoeuvring according to a carefully prepared judicial strategy.

With the true pathos of a judicial idealist, THOMAS FRANCK has described the political question doctrine, the American version of the doctrine de maximis non curat praetor, as the price Chief Justice JAMES MARSHALL had to pay when he 'bought' judicial review from the devil, which in the allegory represents the holders of political power (sic!). If, similarly, the Hague Court by retreating from the legalism displayed in the Nicaragua Judgment and accepting the doctrine de maximis non curat praetor in a version which would be determined and controlled by the Court itself, could make way for a moderate version of judicial review, this would perhaps not be such a bad manoeuvre. ${ }^{37}$ What may appear to be a pact with the devil to a judicial idealist in the highly integrated United States, would not necessarily appear an equally repugnant deal to the Court of the United Nations.

37 There are in fact, as we may learn from comparative constitutional law, several moderate versions of judicial review which have been developed in theory and/or practice on a national or regional level over the years. The following points may be considered. Firstly, of course, the very acceptance of the doctrine de maximis... implies a moderation of judicial power. Secondly, the Court may wish to restrict its power of review to acts which are clearly unconstitutional, thus accepting a broad margin of appreciation on the part of the political organs. Such an approach could be inspired by, inter alia, the reasonable doubt test of US Constitutional Theory (its originator being J.B. THAYER, 'The Origin and Scope of the American Doctrine of Constitutional Law', 7 Harvard Law Review (1893) at 129-156); the doctrine of margin of appreciation of the European Court of Human Rights or the criteria of obviousness ("uppenbarhetsrekvisitet") of Swedish constitutional law. Thirdly, the Court may take the view that, although it may and shall take a stand on all legal issues which are submitted to it, its pronouncements cannot be supreme or final in relation to any other entities than the parties to the case. This model, which can claim some support from article 59 of the Court's Statute as well as from the travaux préparatoires of the UN Charter, may find a theoretical basis in the doctrine of concurrent (or 'Jeffersonian') review of US constitutional theory. On 'Jeffersonian' review as a model for the Hague Court, see WATSON, supra n. 32 at pp. 39-43. See also, in this context, F. DANELIUS, 'The Charter as Lex Superior and the Passive Virtues', paper presented at the UN Congress of Public International Law (New York, March 13-17, 1995). 